\title{
Simulation Research on the Heating Performance of the Combined System of Solar Energy and Heat-Source Tower Heat Pump in a Hot Summer and Cold Winter Area
}

\author{
Xiaohang Shen, Nianping $\mathrm{Li}^{*}$ and Yongga $\mathrm{A}$ \\ College of Civil Engineering, Hunan University, Changsha 410082, China; B1201S006@hnu.edu.cn (X.S.); \\ ayg5120@hnu.edu.cn (Y.A.) \\ * Correspondence: linianping@hnu.edu.cn
}

Citation: Shen, X.; Li, N.; A, Y Simulation Research on the Heating Performance of the Combined System of Solar Energy and Heat-Source Tower Heat Pump in a Hot Summer and Cold Winter Area. Energies 2021, 14, 1816. https://doi.org/10.3390/ en14071816

Academic Editor: Angelo Zarrella

Received: 10 February 2021

Accepted: 18 March 2021

Published: 24 March 2021

Publisher's Note: MDPI stays neutral with regard to jurisdictional claims in published maps and institutional affiliations.

Copyright: (c) 2021 by the authors. Licensee MDPI, Basel, Switzerland. This article is an open access article distributed under the terms and conditions of the Creative Commons Attribution (CC BY) license (https:// creativecommons.org/licenses/by/ $4.0 /)$.

\begin{abstract}
Three connection methods for the combined heating systems of a closed-type heat-source tower heat pump (CHTHP) and solar collector (SC) were proposed in this paper: the heat-source tower (HST) and solar collector were connected in series (HST+SC), and the solar collector and heat pump (HP) condenser were connected in series (SC+HP) and in parallel (SC//HP). The calculation module of the closed heat-source tower was built using programming software based on $\mathrm{C}++$ language, and three corresponding calculation models of the combined heating systems were established in the TRNSYS. Under the climatic conditions of the cold season in Changsha, the combined heating performance of the three systems was simulated and analyzed. The results indicate that the simulation results of the established models are in good agreement with the test results, and the simulation results can be used for the research of the system's combined heating performance. When the outdoor air temperature and solar radiation intensity are low, the HST+SC system has the best heating performance; however, when the solar radiation intensity and ambient temperature are high, the heating performance of the SC/ / HP system is the best. When the solar radiation intensity and outdoor air temperature are between the previous two working conditions, the SC+HP system is the best performer for heating among the three systems. On the basis of the collector area and heat pump power designed in this study, the best operating condition interval diagrams of the three combined heating systems are established.
\end{abstract}

Keywords: solar energy; heat pump; combined heating; energy saving technology

\section{Introduction}

As residents' living standards are continuously improved, the demand for building heating energy consumption will gradually increase, thus making full use of renewable energy becomes a momentous method to meet the increasing demand of building heating energy consumption [1-3]. Solar water heating systems and air source heat pump (ASHP) systems are widely used in people's lives because of their energy-saving properties and low cost of use $[4,5]$. They not only provide ecological solutions for heat generation, but also increase energy independence [6]. However, there are still some shortcomings limiting the further development of solar thermal utilization technology and ASHP technology, such as the intermittence and low energy density of solar energy [7] and the phenomenon that the evaporator of the ASHP may be frosted in a low temperature environment, which leads to a decrease in heating capacity and Coefficient of Performance (COP) [8]. For the purpose of effectively solving the frosting problem in ASHP applications, the heat-source tower technology was put forward [9].

The heat-source tower technology originated in 1980 (Japan) [10], and similar to cooling towers, heat-source towers had high heat exchange efficiency [11]. The heat-source tower can not only serve as a cooling tower in summer, but can also fully absorb heat from low-temperature air to provide heat for heat pumps in winter and solve the frosting 
problem of heat pumps simultaneously. Open/closed-type heat-source towers are two basic types of heat-source towers, which are divided according to the different contact forms of the heat exchange medium in the heat-source tower. The open-type heat-source tower has a relatively simple structure, which is an important research direction of the early heat-source tower. Liang et al. [12] constructed an open-type heat-source tower heat pump (OHTHP) test device and discovered that the system has a good heating effect and almost completely avoided the ASHP frosting problem. Huang et al. [8] used a numerical method to compare and analyze the performance of OHTHP and traditional ASHP, and discovered that compared with traditional ASHP, the efficiency of OHTHP in summer and winter increased by $23.1 \%$ and $7.4 \%$, respectively. Lu et al. [13] established the prediction correlation of heat and mass transfer of an open-type heat-source tower by theoretical analysis and a numerical method. Fujita et al. [14] fitted the relationship between the mass transfer coefficient and gas-liquid flow through experiments. Huang et al. $[15,16]$ studied and built the correlation between the heat and mass transfer coefficient and spray density and air flow density, and established the physical model of heat-source tower heat pump (HTHP) system optimization. Wen et al. $[17,18]$ analyzed and optimized the heat and mass transfer characteristics, solution regeneration and liquid-gas ratio of the OHTHP.

Although the open-type heat-source tower has many advantages such as high heat exchange efficiency, the problems such as the spilling of circulating fluid and unstable concentration are the key factors restricting its promotion and application. The closed-type heat-source tower has gradually attracted the attention of researchers due to its good ability to solve these problems. Li et al. [11] studied the energy efficiency performance of the closed-type heat-source tower heat pump (CHTHP) system and discovered that under the conditions of $-1{ }^{\circ} \mathrm{C}-5{ }^{\circ} \mathrm{C}$ air dry bulb temperature and $71-95 \%$ relative humidity, the system's COP could be up to 2.58-4.34. Zhang et al. [19] evaluated the influence of various parameters on the thermal performance of a heat-source tower through simulation. Li et al. studied the impact of air parameter change on the performance of CHTHP experimentally $[20,21]$, and found the CHTHP system efficiency could be promoted by $5-11 \%$ after starting a spray system to prevent frost [22,23]. Song et al. [24,25] explored the impact of different heat transfer media on the heat transfer performance of CHTHP, and discovered that the heat transfer capacity of the glycerol solution system was higher than that of the $\mathrm{CaCl}_{2}$ solution (1.3-1.7 times).

The current research on heat-source towers mainly focuses on their thermal performance, heat and mass transfer theoretical characteristics, and solution regeneration technology. Low-temperature air could be used by a heat-source tower to supply heat for the heat pump to prevent frosting, yet the air temperature would affect the heat utilization efficiency of the heat-source tower.

The lower the air temperature, the lower the heat utilization efficiency of the heatsource tower. When assisted by other heat sources, the operating energy efficiency of the heat-source tower could be improved [26]. The combined system of HTHP and solar water will also improve the system's utilization efficiency of renewable energy [27]. However, there are only a few studies on the combined heating technology of a heat-source tower and solar energy. As a kind of equipment integrating heat supply and refrigeration, HTHP can be combined with solar energy in an appropriate way to complement each other, which can not only avoid the poor performance of HTHP at low temperature [28], but also has great development potential in improving the energy utilization efficiency [29]. Feng et al. analyzed the complementary principle of solar thermal utilization technology and a heat source tower heat pump by studying the heating performance of a solar-assisted closed heat-source tower heat pump system in winter [30]. Zhang et al. tested the performance of different heat carrying fluids in the solar collector and heat exchanger of a heat-source tower heat pump and concluded that glycerol solution was a favorable working fluid [31]. Xia et al. studied the system performance of the solar-heat source tower heat pump load air conditioning system, and the results showed that under the combined heating condition of the heat pump unit and the heat storage tank, the heating effect of the system was good 
with the water temperature higher than $12{ }^{\circ} \mathrm{C}$ in the heat storage tank, and the system COP could be stable at about 3.6 [32]. Shi et al. analyzed the performance of the solar hot water system for heat pump auxiliary heating of the heat-source tower, and they found that the system had an obvious annual energy saving effect and the solar energy guarantee rate was as high as $72 \%$ [33].

In summary, the combined heating system of a heat-source tower heat pump and solar collector was conducive to give full play to the advantages of each energy system, comprehensively improving energy utilization efficiency and system stability. There are mainly three connection modes: heat pump and solar collector in parallel, heat pump and solar collector in series, and heat-source tower and solar collector in parallel as a heat pump heat source. Outdoor air temperature and solar radiation intensity were important parameters affecting the energy efficiency of the combined heating system. When the two changed, the energy utilization efficiency of the combined heating system of each connection mode had a different trend. However, there is still a lack of research in this area. Therefore, in order to study the variation in the energy efficiency of the combined heating system with solar radiation intensity and ambient air temperature, according to the different connection methods of solar collectors and heat-source tower heat pumps, this paper studied the energy efficiency trend of three combined heating systems. The calculation module of the closed heat-source tower was compiled using $\mathrm{C}++$ language, and TRNSYS models of three types of combined heating systems were established. In winter, three types of combined heating systems were simulated and analyzed, and the corresponding optimal energy efficiency range diagrams were drawn.

\section{Mathematical Model}

\subsection{System Composition}

In this paper, combined heating systems of solar energy and a closed-type heat-source tower were introduced, which mainly consisted of solar collectors, a closed-type heatsource tower, a water pump, a water source heat pump (WSHP), and a water storage tank. There are multiple combinations of solar collectors and a closed-type heat-source tower. Solar collectors and a heat pump condenser were connected in parallel or in series, which was defined as the SC/ / HP system (Figure 1a) and the SC+HP system (Figure 1b), respectively, in this paper, while the HST+SC system (Figure 1c) represented solar collectors and a heat-source tower connected in series.

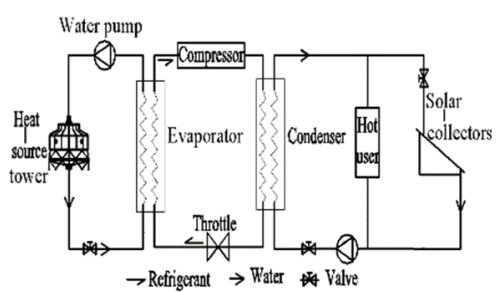

(a)

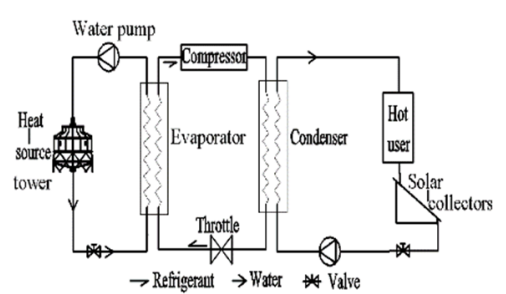

(b)

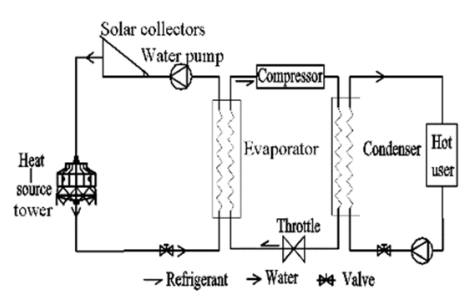

(c)

Figure 1. Schematic diagram of three heating systems: (a) SC//HP, (b) SC+HP, (c) HST+SC.

\subsection{Heat and Mass Exchange Models of Heat-Source Tower Heat Exchanger}

According to the relationship between the heat exchange's outer surface temperature and the air temperature at the heat-source tower's inlet, the heat and mass exchange process of the heat-source tower can be divided into dry conditions and wet conditions. When the heat exchange's outer surface temperature is higher than the air temperature at the heat-source tower's inlet, the heat-source tower heat exchanger will operate under dry conditions, whereas when the outer surface temperature is lower than the inlet air temperature, the heat-source tower heat exchanger will operate under wet conditions. Heat and mass exchange models of the heat-source tower heat exchanger were established under different conditions. 


\subsubsection{Heat and Mass Transfer Process Analysis under Dry Conditions in Winter}

There is no condensed water on the heat-source tower heat exchanger surface under dry conditions, thus the heat released by air in the heat-source tower heat exchanger is completely sensible heat. The efficiency-number of heat transfer unit $(\varepsilon-N T U)$ method was used to calculate the heat and mass exchange process of the heat-source tower heat exchanger in the heat-source tower. Based on the fact that only sensible heat exchange between the circulating fluid and wet air existed under dry conditions, the heat capacity ratio and the number of heat transfer units of the heat-source tower heat exchanger were calculated first using Equations (1) and (2) to figure out the exchange process of the heatsource tower heat exchanger:

$$
\begin{aligned}
\mathrm{C}_{\mathrm{d}} & =\frac{\mathrm{m}_{\mathrm{a}} \mathrm{C}_{\mathrm{pa}}}{\mathrm{m}_{\mathrm{w}} \mathrm{C}_{\mathrm{pw}}} . \\
\mathrm{NTU}_{\mathrm{d}} & =\frac{\eta_{\mathrm{d}} \times \mathrm{NTU}_{\mathrm{O}}}{1+\frac{\eta_{\mathrm{d}} \times \mathrm{NTU}_{\mathrm{O}}}{\mathrm{C}_{d} \times \mathrm{NTU}_{\mathrm{I}}}}
\end{aligned}
$$

where $\mathrm{NTU}_{\mathrm{I}}$ and $\mathrm{NTU}_{\mathrm{O}}$ are the number of heat exchange units inside and outside the heatsource tower heat exchanger, respectively, which can be calculated by Equations (3) and (4):

$$
\begin{gathered}
\mathrm{NTU}_{\mathrm{I}}=\frac{\mathrm{A}_{\mathrm{l}}}{\mathrm{m}_{\mathrm{w}} \mathrm{C}_{\mathrm{pw}}\left(\frac{1}{\mathrm{~h}_{\mathrm{i}}}+\mathrm{r}_{\mathrm{W}}\right)} \\
\mathrm{NTU}_{\mathrm{o}}=\frac{\mathrm{A}_{\mathrm{o}} \mathrm{h}_{\mathrm{o}}}{\mathrm{m}_{\mathrm{a}} \mathrm{C}_{\mathrm{pa}}}
\end{gathered}
$$

The $r_{w}$ in Equation (3) represents the thermal resistance of the tube wall per unit surface area, which can be obtained using Equation (5):

$$
\mathrm{r}_{\mathrm{w}}=\frac{\mathrm{R}_{\mathrm{I}} \times \ln \frac{\mathrm{R}_{\mathrm{O}}}{\mathrm{R}_{\mathrm{I}}}}{\mathrm{K}_{\mathrm{T}}}
$$

When the number of rows of the heat-source tower heat exchanger's finned tube is more than four, the flow contact mode of the internal and external fluids is close to countercurrent [34]. The number of rows of the heat-source tower heat exchanger's finned tube in the closed-type heat-source tower is generally more than four, which can be analyzed as countercurrent heat-source tower heat exchanger. Therefore, the heat exchange efficiency of the heat-source tower heat exchanger's finned tube in the heat-source tower could be given as Equation (6):

$$
\varepsilon_{\mathrm{d}}=\frac{\mathrm{T}_{\mathrm{ai}}-\mathrm{T}_{\mathrm{ao}}}{\mathrm{T}_{\mathrm{ai}}-\mathrm{T}_{\mathrm{wi}}}=\frac{1-\exp \left[-\mathrm{NTU}_{\mathrm{d}}\left(1-\mathrm{C}_{\mathrm{d}}\right)\right]}{1-\mathrm{C}_{\mathrm{d}} \exp \left[-\mathrm{NTU}_{\mathrm{d}}\left(1-\mathrm{C}_{\mathrm{d}}\right)\right]}
$$

The heat absorption of the circulating fluid can be determined by Equation (7):

$$
\mathrm{Q}_{\mathrm{d}}=\varepsilon_{\mathrm{d}} \mathrm{m}_{\mathrm{a}} \mathrm{C}_{\mathrm{pa}}\left(\mathrm{T}_{\mathrm{ai}}-\mathrm{T}_{\mathrm{wi}}\right)
$$

The outlet temperatures of the air $\left(\mathrm{T}_{\mathrm{ao}}\right)$ and the circulating fluid $\left(\mathrm{T}_{\mathrm{wo}}\right)$ can be obtained by Equations (8) and (9):

$$
\begin{aligned}
& \mathrm{T}_{\mathrm{ao}}=\mathrm{T}_{\mathrm{wi}}+\varepsilon_{\mathrm{d}}\left(\mathrm{T}_{\mathrm{ao}}-\mathrm{T}_{\mathrm{wi}}\right) \\
& \mathrm{T}_{\mathrm{wo}}=\mathrm{T}_{\mathrm{wi}}+\mathrm{C}_{\mathrm{d}}\left(\mathrm{T}_{\mathrm{ai}}-\mathrm{T}_{\mathrm{ao}}\right)
\end{aligned}
$$

The outer surface temperature of the heat-source tower heat exchanger at the air outlet can be obtained by Equation (10):

$$
\mathrm{T}_{\mathrm{so}}=\mathrm{T}_{\mathrm{wi}}+\mathrm{C}_{\mathrm{d}}\left(\frac{\mathrm{NTU}_{\mathrm{d}}}{\mathrm{NTU}_{\mathrm{I}}}\right)\left(\mathrm{T}_{\mathrm{ao}}-\mathrm{T}_{\mathrm{wi}}\right)
$$

\subsubsection{Heat and Mass Transfer Process Analysis under Wet Conditions in Winter}

The efficiency-number of heat transfer units $(\varepsilon-\mathrm{NTU})$ method was adopted in the calculation of the heat-source tower heat exchanger's heat and mass transfer process 
under mixed wet conditions. When the heat-source tower heat exchanger operated under mixed wet conditions, the position of the mixing point could be determined by the proportion $\left(f_{d}\right)$ of the dry surface of the heat-source tower heat exchanger to its whole surface (Equations (11) and (12)). When there is no dry surface on the heat-source tower heat exchanger surface, $\mathrm{f}_{\mathrm{d}}=0$.

$$
\begin{gathered}
\mathrm{f}_{\mathrm{d}}=-\frac{1}{\mathrm{k}} \ln \left[\frac{\left(\mathrm{T}_{\mathrm{dp}}-\mathrm{T}_{\mathrm{wo}}\right)+\mathrm{C}_{\mathrm{d}}\left(\mathrm{T}_{\mathrm{ai}}-\mathrm{T}_{\mathrm{dp}}\right)}{\left(1-\frac{\mathrm{k}}{\mathrm{NTU}_{\mathrm{o}}}\right)\left(\mathrm{T}_{\mathrm{ai}}-\mathrm{T}_{\mathrm{ao}}\right)}\right] \\
\mathrm{k}=\mathrm{NTU}_{\mathrm{d}}\left(1-\mathrm{C}_{\mathrm{d}}\right) .
\end{gathered}
$$

The heat transfer efficiency of the dry surface $\left(\varepsilon_{d}\right)$ and wet surface $\left(\varepsilon_{w}\right)$ of the heatsource tower heat exchanger can be calculated by Equations (13) and (14):

$$
\begin{gathered}
\varepsilon_{d}=\frac{1-\exp \left[-N_{T} U_{d} f_{d}\left(1-C_{d}\right)\right]}{1-C_{d} \exp \left[-N_{T} U_{d} f_{d}\left(1-C_{d}\right)\right]} \\
\varepsilon_{W}=\frac{1-\exp \left[-N T U_{w}\left(1-f_{d}\right)\left(1-C_{w}\right)\right]}{1-C_{w} \exp \left[-N_{T}\left(1-f_{d}\right)\left(1-C_{w}\right)\right]}
\end{gathered}
$$

The circulating fluid's outlet temperature can be obtained using Equations (15) and (16):

$$
\begin{gathered}
\mathrm{T}_{\mathrm{wo}}=\mathrm{C}_{\mathrm{d}} \varepsilon_{\mathrm{d}}\left(\mathrm{T}_{\mathrm{ai}}-\mathrm{T}_{\mathrm{wx}}\right)+\mathrm{T}_{\mathrm{wx}} \\
\mathrm{T}_{\mathrm{wx}}=\frac{\mathrm{T}_{\mathrm{wi}}+\frac{\mathrm{C}_{\mathrm{d}} \varepsilon_{\mathrm{d}}\left(\mathrm{i}_{\mathrm{a} i}-\mathrm{i}_{\mathrm{swi}}\right)}{\mathrm{C}_{\mathrm{pm}}}-\mathrm{C}_{\mathrm{d}} \varepsilon_{\mathrm{d}} \mathrm{T}_{\mathrm{ai}}}{1-\mathrm{C}_{\mathrm{d}} \varepsilon_{\mathrm{d}} \varepsilon_{\mathrm{w}}}
\end{gathered}
$$

The outlet humid air temperature can be calculated by Equations (17) and (20) [34]:

$$
\begin{gathered}
\mathrm{T}_{\mathrm{ao}}=\mathrm{T}_{\mathrm{se}}+\left(\mathrm{T}_{\mathrm{ax}}-\mathrm{T}_{\mathrm{se}}\right) \exp \left[-\left(1-\mathrm{f}_{\mathrm{d}}\right) \mathrm{NTU}_{\mathrm{o}}\right] \\
\mathrm{i}_{\mathrm{se}}=\mathrm{i}_{\mathrm{ax}}+\frac{\mathrm{i}_{\mathrm{ao}}-\mathrm{i}_{\mathrm{ax}}}{1-\exp \left[-\mathrm{NTU}_{\mathrm{o}}\left(1-\mathrm{C}_{\mathrm{d}}\right)\right]} \\
\mathrm{i}_{\mathrm{ax}}=\mathrm{i}_{\mathrm{ai}}-\varepsilon_{\mathrm{d}} \mathrm{C}_{\mathrm{pm}}\left(\mathrm{T}_{\mathrm{ai}}-\mathrm{T}_{\mathrm{wx}}\right) \\
\mathrm{T}_{\mathrm{ax}}=\mathrm{T}_{\mathrm{ai}}-\varepsilon_{\mathrm{d}}\left(\mathrm{T}_{\mathrm{ai}}-\mathrm{T}_{\mathrm{wx}}\right)
\end{gathered}
$$

where $i_{a x}$ and $T_{a x}$ represent the specific enthalpy and temperature of the mixing point, respectively.

The total heat of the circulating fluid can be expressed by Equation (21):

$$
\mathrm{Q}_{\mathrm{w}}=\mathrm{m}_{\mathrm{w}} \mathrm{C}_{\mathrm{pm}}\left(\mathrm{T}_{\mathrm{wo}}-\mathrm{T}_{\mathrm{wi}}\right)
$$

\subsection{Heat Transfer Model of Solar Collector}

The solar collector's efficiency can be obtained through Equation (22), which was supplied by the National Solar Energy Water Quality Supervision and Inspection Center Heater [28].

$$
\eta_{\mathrm{s}}=0.7-4.72 \frac{\left(\mathrm{T}_{\mathrm{wi}}-\mathrm{T}_{\mathrm{a}}\right)}{\mathrm{I}}
$$

The heat-collecting capacity of solar collectors $\left(Q_{S}\right)$ can be obtained through Equation (23) [35].

$$
\mathrm{Q}_{\mathrm{S}}=\mathrm{A}_{\mathrm{S}} \mathrm{I} \eta_{\mathrm{S}}
$$

\subsection{Heat Transfer Model of Water Source Heat Pump}

When the water source heat pump works independently, its heating capacity and input power are mainly related to the circulating fluid's temperature at the evaporator's inlet and the water temperature at the condenser's inlet. Therefore, the heating capacity $\left(Q_{H P}\right)$ and input power $\left(P_{H P}\right)$ of WSHP can be obtained through Equations (24) and (25) [36]:

$$
\mathrm{Q}_{\mathrm{HP}}=\mathrm{a}_{1}+\mathrm{a}_{2} T_{e}+\mathrm{a}_{3} T_{e}^{2}+\mathrm{a}_{4} T_{c}+\mathrm{a}_{5} T_{c}^{2}+\mathrm{a}_{6} T_{e} T_{c}
$$




$$
\mathrm{P}_{\mathrm{HP}}=\mathrm{b}_{1}+\mathrm{b}_{2} \mathrm{~T}_{\mathrm{e}}+\mathrm{b}_{3} \mathrm{~T}_{\mathrm{e}}^{2}+\mathrm{b}_{4} \mathrm{~T}_{\mathrm{c}}+\mathrm{b}_{5} \mathrm{~T}_{\mathrm{c}}^{2}+\mathrm{b}_{6} \mathrm{~T}_{\mathrm{e}} \mathrm{T}_{\mathrm{c}}
$$

The COP of the combined heating systems of solar hot water and the closed-type heat-source tower could be calculated by Equation (26):

$$
\mathrm{COP}_{\text {sys }}=\frac{\mathrm{Q}_{\mathrm{g}}}{\mathrm{W}}
$$

The system's heating and input power can be obtained through Equations (27) and (28), and in the HST $+\mathrm{SC}$ system, $Q_{S}=0$.

$$
\begin{gathered}
\mathrm{Q}_{\mathrm{g}}=\mathrm{Q}_{\mathrm{HP}}+\mathrm{Q}_{\mathrm{S}} \\
\mathrm{W}=\mathrm{P}_{\mathrm{HP}}+\mathrm{W}_{\mathrm{WP}}
\end{gathered}
$$

\section{TRNSYS Calculation Module for Closed-Type Heat-Source Tower}

\subsection{Establishment of TRNSYS Calculation Module}

Based on the mathematical model of the closed-type heat-source tower established above, the TRNSYS calculation module for the heat-source tower was built by using $\mathrm{C}++$ language. The calculation module was imported into the Simulation Studio for the verification of the heat-source tower module and the simulation calculation of the combined heating system with solar energy and a heat-source tower heat pump. These corresponding parameters, inputs and outputs of the closed-type heat-source tower calculation module built by TRNSYS in this study are given in Table 1.

Table 1. The parameters, inputs and outputs of TRNSYS calculation module.

\begin{tabular}{ll}
\hline Parameters. & Item \\
\hline \multirow{2}{*}{ Attributes } & $\begin{array}{l}\text { Inner/Outer diameter of copper pipe; Thermal conductivity of copper pipe; Fin thickness; Fin pitch; Number of fins; Thermal } \\
\text { conductivity of fins; Circulating fluid's specific heat capacity; Air specific heat capacity; Maximum fan power; Number of rows of pipes } \\
\text { along the airflow direction; Number of rows of pipes in vertical airflow direction; The length of the pipe parallel to the windward side } \\
\text { of heat-source tower heat exchanger; The length of the pipe perpendicular to the windward side of heat-source tower heat exchanger; } \\
\text { Distance between pipe centers along the direction of airflow; Distance between pipe centers in vertical airflow direction }\end{array}$ \\
\hline Inputs & $\begin{array}{l}\text { Inlet air's dry bulb temperature; Air mass flow; Inlet air humidity; Inlet circulating fluid temperature; Mass flow of circulating fluid; } \\
\text { Fan frequency }\end{array}$ \\
\hline Outputs & $\begin{array}{l}\text { Outlet air's dry bulb temperature; Air mass flow; Outlet circulating fluid temperature; Mass flow of circulating fluid; Heat transfer } \\
\text { of heat-source tower; Fan power }\end{array}$ \\
\hline
\end{tabular}

\subsection{Verification of TRNSYS Calculation Module}

\subsubsection{Experimental Setup}

The experimental setup of the CHTHP system was built in Changsha, which mainly consisted of a heat-source tower and a water source heat pump. The heat-source tower and the heat pump condenser were connected with water pipes, and the circulating fluid circulated between them. The circulating fluid absorbed heat from the air in the heat-source tower, then entered the heat pump condenser after heating up and transferred the heat to the refrigerant, and the cooled circulating fluid flowed out of the heat pump condenser and entered the heat-source tower again. According to the climate characteristics of Changsha, $22 \%$ ethylene glycol aqueous solution was used as the circulating liquid, and its freezing point is $-10.7^{\circ} \mathrm{C}$. The experimental set-up schematic is shown in Figure 2. The photo of the field experiment device is presented in Figure 3.

The external dimensions of the heat-source tower heat exchanger's finned tube in the heat-source tower were $820 \mathrm{~mm} \times 820 \mathrm{~mm} \times 320 \mathrm{~mm}$ (length $\times$ width $\times$ height), the fin material was aluminum foil, and the pipe material was brass. The relevant parameters of the heat-source tower heat exchanger are displayed in Table 2. 


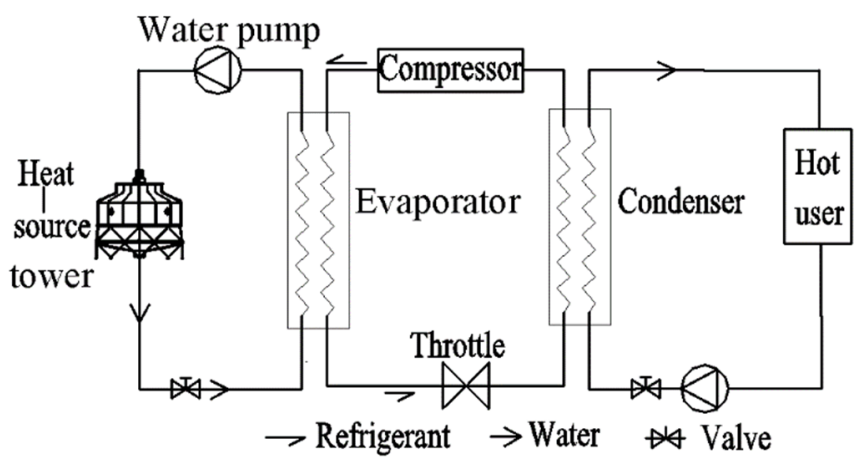

Figure 2. Experimental set-up schematic.

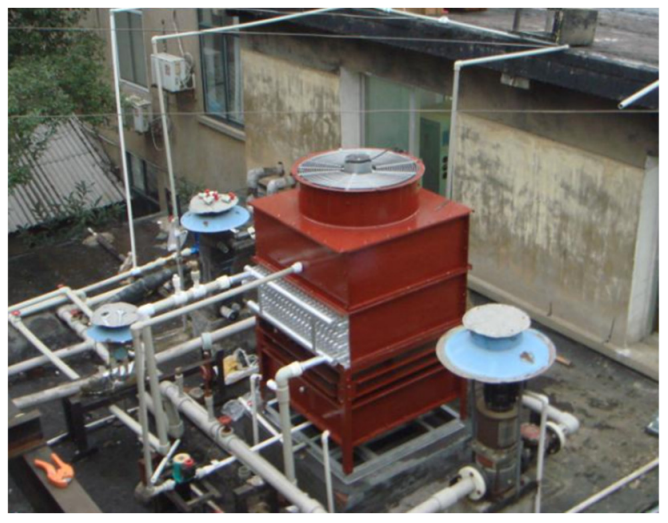

(a)

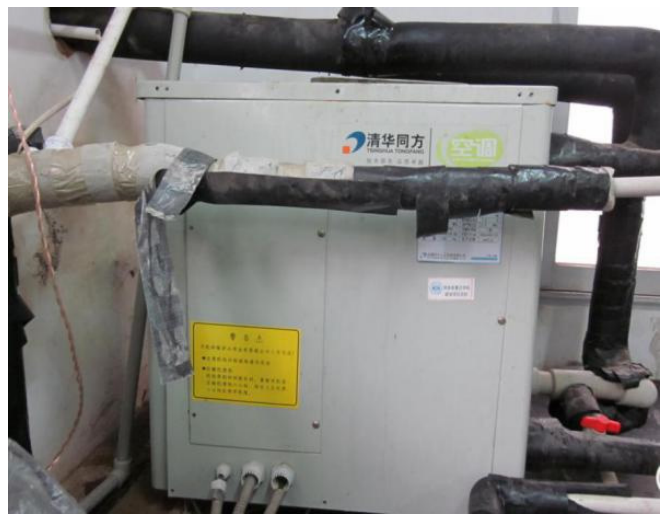

(b)

Figure 3. Photo of experimental device: (a) heat-source tower (b) water source heat pump.

Table 2. The relevant parameters of heat-source tower heat exchanger.

\begin{tabular}{|c|c|c|c|}
\hline Table & Value & The Structural Parameters & Value \\
\hline Number of rows of pipes along the airflow direction & 8 & Fin thickness & $0.3 \mathrm{~mm}$ \\
\hline Number of rows of pipes in vertical airflow direction & 21 & Fin pitch & $6 \mathrm{~mm}$ \\
\hline Distance between pipe centers along the direction of airflow & $33 \mathrm{~mm}$ & Number of fins & 130 \\
\hline Distance between pipe centers in vertical airflow direction & $38 \mathrm{~mm}$ & Outer diameter of copper pipe & $16 \mathrm{~mm}$ \\
\hline $\begin{array}{l}\text { Length of the pipe perpendicular to the windward side of } \\
\text { heat-source tower heat exchanger }\end{array}$ & $820 \mathrm{~mm}$ & Inner diameter of copper pipe & $14 \mathrm{~mm}$ \\
\hline $\begin{array}{c}\text { Length of the pipe parallel to the windward side of } \\
\text { heat-source tower heat exchanger }\end{array}$ & $820 \mathrm{~mm}$ & Copper tube thickness & $1 \mathrm{~mm}$ \\
\hline
\end{tabular}

\subsubsection{Test Methods}

The experimental measurement values mainly included the air's dry bulb temperature at the inlet and outlet of the heat-source tower, the inlet and outlet temperature of the circulating fluid, the air flow, and the circulating fluid flow. In the experimental test, platinum resistance temperature sensors were applied to test the air's dry bulb temperatures at the heat-source tower's inlet and outlet, and the assembled platinum resistance temperature sensors were applied to measure the circulating fluid's inlet and outlet temperature. All temperature data were stored in the paperless recorder in which the measured values could be read. The air velocity was measured by a hand-held anemometer. Multiple air velocity measurement points were set at the air outlet, and the average of their corresponding measured values was taken as the air velocity. The air flow could be calculated by using the air velocity and the cross-sectional area of air flow. The ultrasonic flow meter was employed to measure the glycol solution flow, the density meter was used to measure the concentration of the ethylene glycol aqueous solution, and solar irradiance was measured 
by the sc- 1 solar radiation recorder. The measurement parameters of each instrument are displayed in Table 3.

Table 3. The measurement parameters of test instruments.

\begin{tabular}{|c|c|c|c|}
\hline Instruments & Type & Measurement Range & Accuracy \\
\hline Assembled platinum resistance temperature sensor & PT100 & $-50-100{ }^{\circ} \mathrm{C}$ & $\pm 0.1^{\circ} \mathrm{C}$ \\
\hline Platinum resistance temperature sensor & PT100 & $-50-100{ }^{\circ} \mathrm{C}$ & $\pm 0.1^{\circ} \mathrm{C}$ \\
\hline Hand-held anemometer & TSI8347 & $0-30 \mathrm{~m} / \mathrm{s}$ & $\pm 0.01 \mathrm{~m} / \mathrm{s}$ \\
\hline Ultrasonic flow meter & P204 & $\begin{array}{l}\text { Flow rate: } 0.12-12.39 \mathrm{~m} / \mathrm{s} \\
\text { Pipe diameter } 12-115 \mathrm{~mm}\end{array}$ & $\pm 0.1 \%$ \\
\hline Density meter & & $1.100-1.200 \mathrm{~g} / \mathrm{cm}^{3}$ & $\pm 0.001 \mathrm{~g} / \mathrm{cm}^{3}$ \\
\hline Paperless recorder & EN880-X-48 & & Storage accuracy 16 bits \\
\hline Solar radiation recorder & SC-1 & $0-2000 \mathrm{~W} / \mathrm{m}^{2}$ & $\pm 2 \%$ \\
\hline
\end{tabular}

\subsubsection{Data Validity Judgment}

The heat released by air and the heat absorbed by circulating fluid can be expressed as Equations (29) and (30), respectively:

$$
\begin{gathered}
\mathrm{Q}_{\mathrm{w}}=\mathrm{C}_{\mathrm{w}} \mathrm{q}_{\mathrm{w}}\left(\mathrm{T}_{\mathrm{wo}}-\mathrm{T}_{\mathrm{wi}}\right) \\
\mathrm{Q}_{\mathrm{a}}=\mathrm{C}_{\mathrm{a}} \mathrm{q}_{\mathrm{a}}\left(\mathrm{T}_{\mathrm{ai}}-\mathrm{T}_{\mathrm{ao}}\right)
\end{gathered}
$$

Based on the law of conservation of energy, the heat release of air should be exactly equal to the heat absorption of circulating fluid. However, in actual situations, the results might not be completely accurate due to the equipment and human factors. For the purpose of proving the accuracy and validity of the measured value, the relative error between the heat released by air and the heat absorbed by circulating fluid was adopted for analysis (Equation (31)):

$$
\delta=\frac{\left|Q_{\mathrm{w}}-\mathrm{Q}_{\mathrm{a}}\right|}{\mathrm{Q}_{\mathrm{a}}} \times 100 \%
$$

When the relative error is within $\pm 10 \%$, the visible measurement values can be regarded as valid data, which can be applied to verify the calculation model's accuracy.

\subsubsection{Comparative Analysis of Experimental and Simulated Results}

According to the previously established calculation module of the heat-source tower, by entering the parameters of the experimental equipment in the TRNSYS model, and referring to the changes in both the outdoor air's dry bulb temperature and the circulating fluid's inlet temperature during experiments, the circulating fluid's temperature at the heatsource tower outlet and the heat transfer amount of the heat-source tower were simulated.

The relative error (RE) and the mean relative error (MRE) were used to analyze the deviation between the simulated value and the experimental value. The RE and MRE can be calculated by Equations (32) and (33):

$$
\begin{aligned}
& R_{\mathrm{i}}=\frac{\left|\mathrm{Tm}_{\mathrm{i}}-\mathrm{Te}_{\mathrm{i}}\right|}{\mathrm{Te}_{\mathrm{i}}} \\
& \mathrm{MRE}=\frac{\sum_{\mathrm{i}=1}^{\mathrm{n}} \mathrm{RE}_{\mathrm{i}}}{\mathrm{n}}
\end{aligned}
$$

Twenty groups of operating condition points were selected for comparison, and the experimental and simulated values of the circulating fluid's outlet temperature and the heat-source tower's heat transfer were obtained. The corresponding comparison results are displayed in Figure 4 and the maximum RE and MRE between the experiments and simulation results are listed in Table 4. 

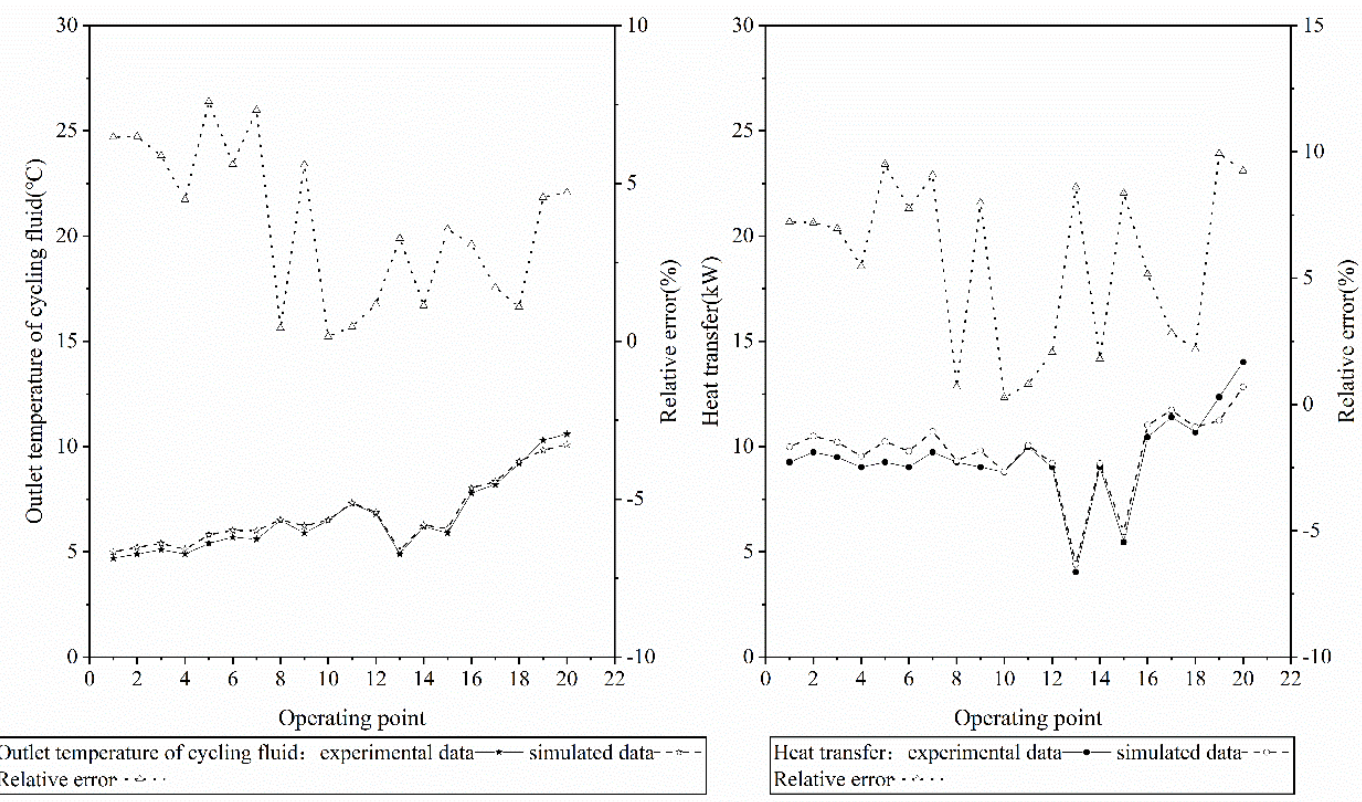

Figure 4. Comparison of experimental and simulated values of circulating fluid's outlet temperature and the heat-source tower's heat transfer.

Table 4. The mean relative error (MRE) and $\mathrm{RE}_{\max }$ between experiments and simulation results.

\begin{tabular}{ccc}
\hline Comparison of Experimental and Simulated Results & Circulating Fluid Outlet Temperature & Heat Transfer Amount \\
\hline $\operatorname{MRE}(\%)$ & 3.74 & 5.66 \\
$\operatorname{RE}_{\max }(\%)$ & 7.32 & 9.94 \\
\hline
\end{tabular}

It can be obtained from Figure 4 that the RE between the experiments and simulation results of the circulating fluid's outlet temperature was small, the maximum $R E$ (RE $E_{\max }$ ) was $7.32 \%$, and the MRE was $3.74 \%$, indicating a good consistency between them. It can also be obtained from Figure 4 that the deviation between the experiments and simulation results of heat transfer between the air of the heat-source tower and the circulating fluid was small, with an MRE of $5.66 \%$ and a maximum RE of $9.94 \%$. From the above analysis, it can be found that the TRNSYS calculation module of the heat-source tower built using C++ language in this work had good accuracy and could realize the function of the heat-source tower, which laid the foundation for simulation analysis of three combined heating systems with solar energy and a heat-source tower heat pump that would be introduced later.

\section{Simulation Model}

With reference to the system schematic diagrams shown in Figure 1, the TRNSYS model of three combined heating systems of solar collectors and a heat-source tower heat pump were established in simulation studio by using the previously built TRNSYS calculation module of the heat-source tower.

\subsection{Heating Model for SC//HP System}

Solar collectors and a heat pump condenser were connected in parallel in the SC/ /HP system, and after the water storage tank flowed out, it entered the solar collector and the heat pump condenser, respectively. The water flowed through the solar collector and the temperature rose. The air and the circulating fluid exchanged heat in the heat-source tower, and the temperature of the circulating fluid increased. Then, the circulating fluid transferred heat to the refrigerant in the heat pump evaporator, and the refrigerant transferred heat to water flowing through the condenser through refrigerant circulation to raise the water temperature. Eventually, the water heated by the solar collectors and heat pump was combined in the water storage tank for users to use. In this system, solar collectors and the 
heat pump could work independently or complemented each other. The TRYSYS model diagram is shown in Figure 5a.

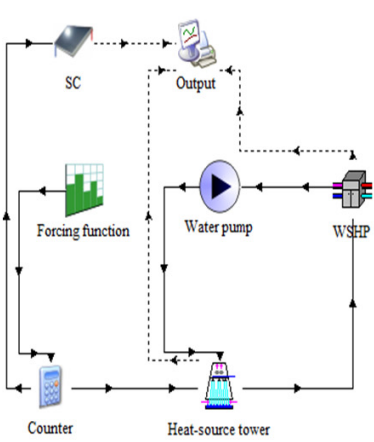

(a)

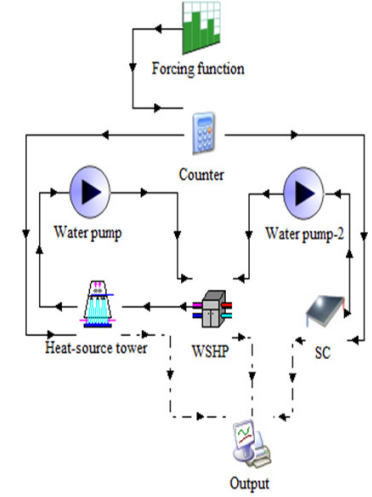

(b)

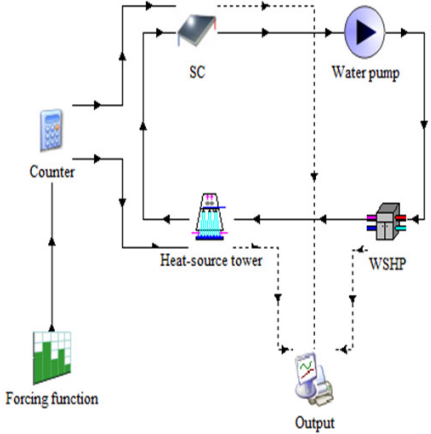

(c)

Figure 5. The TRNSYS model diagram of three combined heating systems: (a) SC//HP (b) SC+HP (c) HST+SC.

\subsection{Heating Model for SC + HP System}

Solar collectors and a heat pump condenser were connected in series in the SC $+\mathrm{HP}$ system. The air, as a heat source of the heat pump, exchanged heat with circulating fluid firstly to heat up the circulating fluid, and the heated circulating fluid entered the watersource heat pump evaporator to transfer heat to the refrigerant. Then, the refrigerant was condensed in the condenser to transfer the heat to hot water. In the SC+HP system, the hot water flowed from the storage tank and then flowed through the solar collectors. After the hot water heated up, it entered the water source heat pump condenser. Finally, the hot water entered the heat storage tank after being heated twice for residents to use. Its corresponding TRNSYS model diagram is shown in Figure $5 b$.

\subsection{Heating Model for HST+SC System}

In the HST+SC system, the circulating fluid entered the heat-source tower after flowing out of the heat pump evaporator, exchanged heat with the air and entered the solar collectors after heating up, and then entered the heat pump evaporator after reheating. This connection method could use solar and air as heat sources of the heat pump at the same time, which could complement each other and improved the refrigerant's evaporation temperature and the heat pump's COP. Figure $5 \mathrm{c}$ shows the TRNSYS model diagram of this system.

\subsection{Parameter Settings}

The relevant parameter settings of solar collectors, the heat pump and the water pump in the TRNSYS simulation are shown in Table 5.

Table 5. Parameter settings of equipment.

\begin{tabular}{ccc}
\hline Equipment. & Parameter & Value \\
\hline & Area & $20 \mathrm{~m}^{2}$ \\
Solar collectors Type1b & Efficiency intercept & 0.7 \\
& Efficiency slope & 17.0 \\
Inclination & $28^{\circ}$ \\
\hline \multirow{2}{*}{ Water source heat pump Type227 } & Rated heating capacity & $11,000 \mathrm{~W}$ \\
Water pump Type3b & Rated power & $3000 \mathrm{~W}$ \\
\hline \multirow{2}{*}{ Water pump Type3b } & Water flow & $2400 \mathrm{~L} / \mathrm{h}$ \\
& Power & $400 \mathrm{~W}$ \\
\hline
\end{tabular}




\section{Simulation Results Analysis}

This paper focused on the influence of solar radiation and outdoor air temperature on the performance of the three systems. The outlet temperature of the fixed hot water storage tank was $40^{\circ} \mathrm{C}$ and the parameter settings of the TRNSYS model of each system are shown in Table 5 . The effects of various factors on different combined heating systems were as follows.

\subsection{The Effect of Solar Radiation Intensity}

The outdoor air temperature was selected as $5^{\circ} \mathrm{C}$ and the solar radiation was $0-900 \mathrm{~W} / \mathrm{m}^{2}$. The temperature change in the circulating fluid at the entrance of the evaporator of each system and the heat transfer of the heat-source tower are shown in Figure 6. The system heat capacity, system input power and system COP changes are shown in Figure 7.

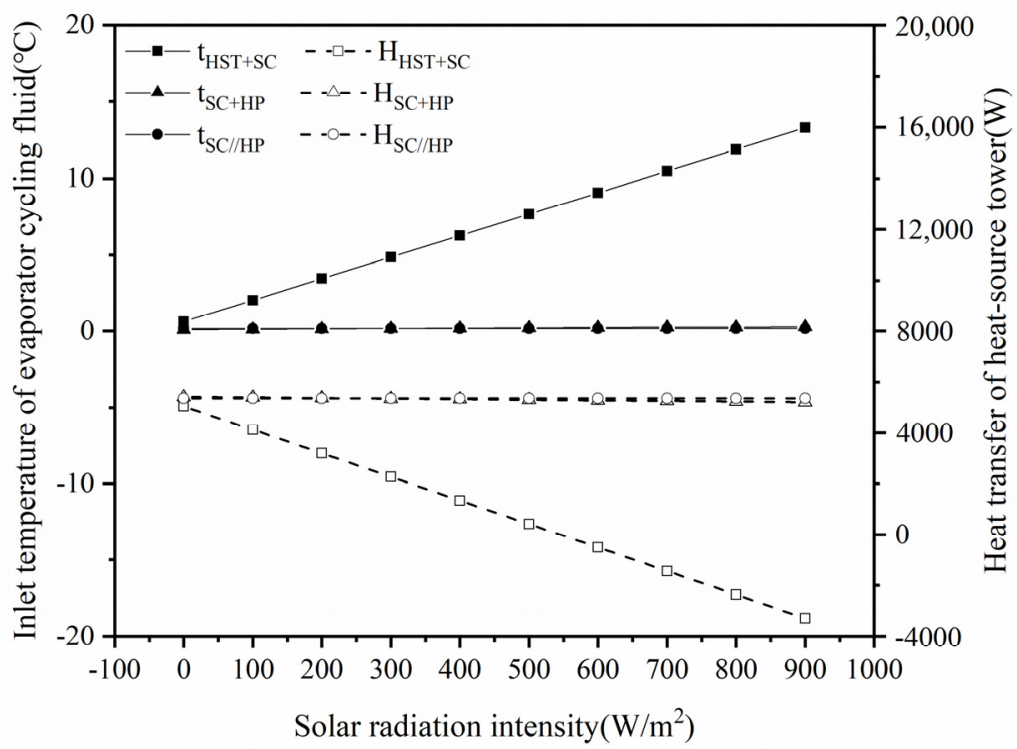

Figure 6. The change in the circulating fluid's temperature at heat pump's inlet and the heat transfer of heat-source tower with the solar radiation intensity $\left(T_{a}=5^{\circ} \mathrm{C}\right)$.

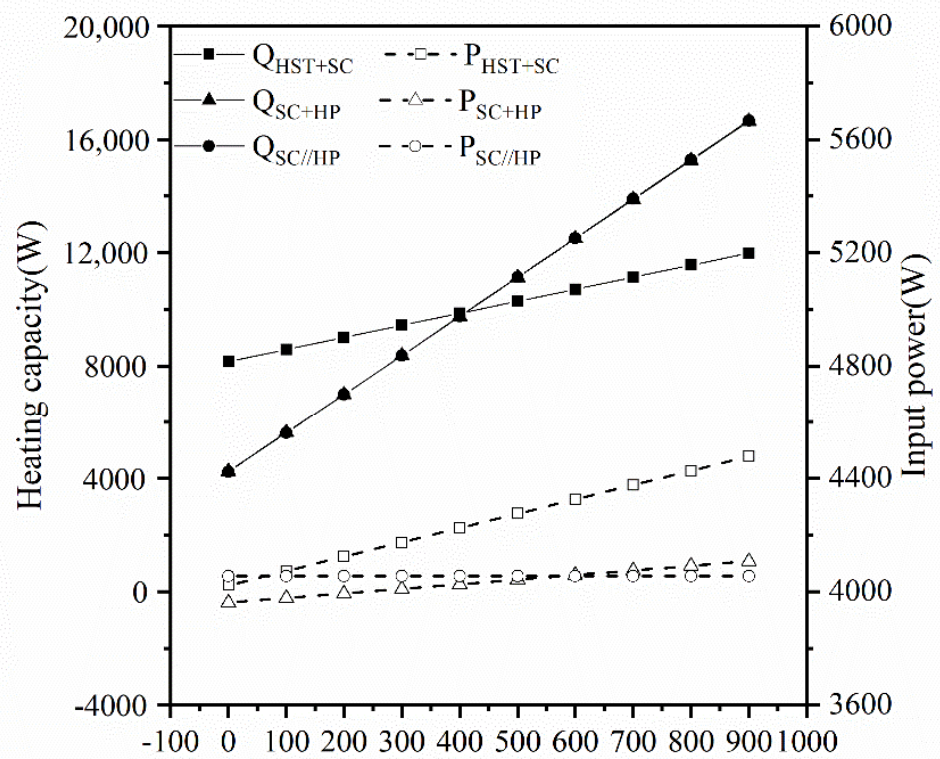

Solar radiation intensity $\left(\mathrm{W} / \mathrm{m}^{2}\right)$

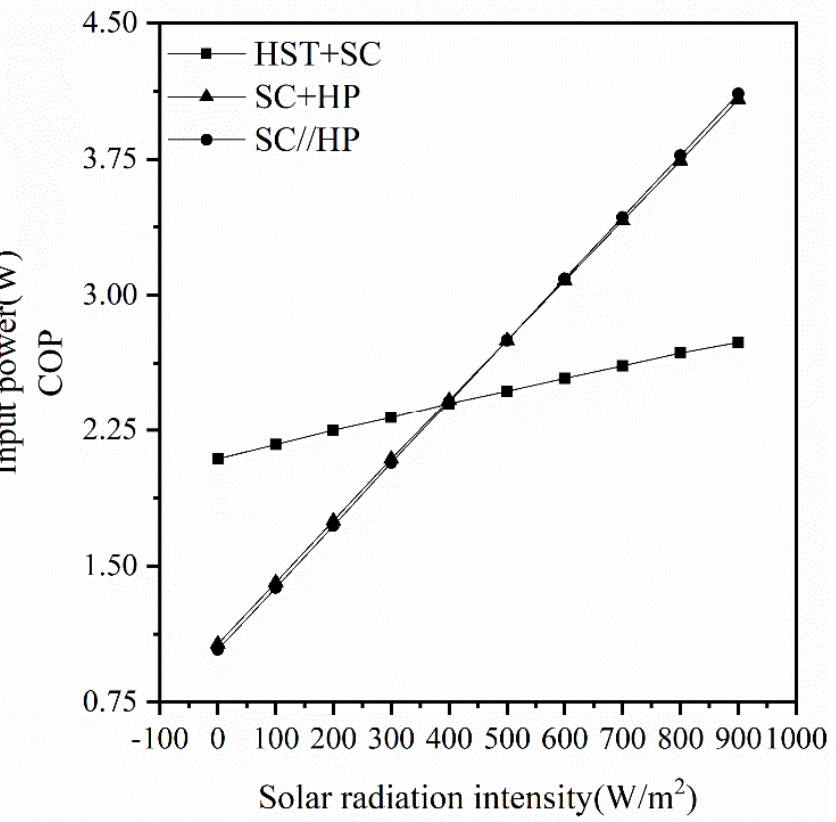

Solar radiation intensity $\left(\mathrm{W} / \mathrm{m}^{2}\right)$

Figure 7. Changes in system heat capacity, input power and Coefficient of Performance $(C O P)\left(T_{a}=5^{\circ} \mathrm{C}\right)$. 
When $T_{a}=5{ }^{\circ} \mathrm{C}$ and I rose from $0 \mathrm{~W} / \mathrm{m}^{2}$ to $900 \mathrm{~W} / \mathrm{m}^{2}$, the simulation temperature results of the circulating fluid at the heat pump evaporator's inlet of each system were obtained without considering the heat loss of the pipeline. Figure 6 shows that the temperature of circulating fluid at the evaporator inlet of the SC/ / HP system remained unchanged, while the HST+SC and SC+HP systems increased the temperature of circulating fluid at the evaporator's inlet, which increased from $0.6{ }^{\circ} \mathrm{C}$ to $13.3^{\circ} \mathrm{C}$ in the HST+SC system. The reason is that under the condition that the mass flow of the circulating fluid is constant, the heat collection of the solar collector increases with the increase in solar radiation, and the temperature of the circulating fluid at the outlet of the collector increases. After flowing out of solar collectors, the circulating fluid entered the heat pump evaporator, and the temperature of circulating fluid at the evaporator inlet increased. The temperature of circulating fluid at the evaporator's inlet in the $\mathrm{SC}+\mathrm{HP}$ system increased from $0.1^{\circ} \mathrm{C}$ to $0.3^{\circ} \mathrm{C}$. This is mainly because the heat collection of the solar collector increased and the heat pump condenser's inlet water temperature increased, thus the heat pump condensation temperature increased and the heating capacity of WSHP decreased. Therefore, the heat released by circulating fluid in the evaporator decreased and the temperature of circulating fluid at the evaporator's outlet increased. Due to the fact that the heat transfer of the heat-source tower was equal to the heat released by circulating fluid in the condenser when the pipe heat loss was not taken into account, the temperature of circulating fluid at the heat-source tower's outlet rose, that is, the temperature of circulating fluid at the heat pump evaporator's inlet improved the temperature of circulating fluid at the evaporator's inlet in the $\mathrm{SC} / / \mathrm{HP}$ system kept unchanged at $0.2^{\circ} \mathrm{C}$. This is because the solar collector was connected in parallel with the heat pump and worked independently, and solar radiation had no effect on the circulating fluid circulation between the heat-source tower and the heat pump system. Hence, the solar radiation intensity did not affect the temperature of circulating fluid at the heat pump evaporator's inlet.

The heat transfer of the heat-source tower in the SC/ / HP system remained unchanged at $5363 \mathrm{~W}$, and the heat transfer of the heat-source tower in the SC+HP system and the HST+SC system decreased from $5424 \mathrm{~W}$ and $5048 \mathrm{~W}$ to $5224 \mathrm{~W}$ and $-3292 \mathrm{~W}$, respectively. When the ambient temperature was constant, the heat transfer of the heat-source tower was mainly affected by the temperature of circulating fluid at the inlet. The higher the temperature of circulating fluid at the heat-source tower's inlet, the smaller the heat transfer of the heat-source tower, whereas the lower the circulating fluid's temperature at the inlet, the larger the heat transfer of the heat-source tower. The temperature of circulating fluid at the heat-source tower's inlet in the three systems was equal to the temperature of circulating fluid at the heat pump evaporator's outlet. When the temperature of circulating fluid at the evaporator's inlet increased, the temperature of circulating fluid at the heat pump evaporator's outlet also increased. The previous analysis shows that when the solar radiation increased, the temperature of circulating fluid at the evaporator's inlet in the $\mathrm{SC} / / \mathrm{HP}$ system remained unchanged, while that of the HST+SC and the SC+HP system increased. Therefore, the heat transfer of the heat-source tower in the $\mathrm{SC} / / \mathrm{HP}$ system remained unchanged, while that in the $\mathrm{HST}+\mathrm{SC}$ and the $\mathrm{SC}+\mathrm{HP}$ system decreased.

When $T_{a}=5{ }^{\circ} \mathrm{C}$ and I rose from $0 \mathrm{~W} / \mathrm{m}^{2}$ to $900 \mathrm{~W} / \mathrm{m}^{2}$, the simulation results of the heating capacity, input power and each system's COP could be obtained without considering the heat loss of the pipeline. Figure 7 shows that the heating capacity of each system increased. The heating capacity of the HST+SC system, SC+HP system and SC/ / HP system increased from $8163 \mathrm{~W}, 4244 \mathrm{~W}$ and $4228 \mathrm{~W}$ to $11,987 \mathrm{~W}, 16,636 \mathrm{~W}$ and 16,672 W, respectively. When solar radiation rose by $100 \mathrm{~W} / \mathrm{m}^{2}$, the heating capacity of the HST+SC, SC+HP and SC / / HP systems increased by $425 \mathrm{~W}, 1377 \mathrm{~W}$, and $1383 \mathrm{~W}$, respectively. The change trends of heating capacity of the three systems were different. This is because the promotion of solar radiation could increase the evaporation temperature of the HST+SC system, but the increase was small. Both the heating capacity of the SC+HP and SC//HP systems was equal to the sum of heat produced by solar collectors and water source heat pumps. The heat collection of the solar collector increased, in the SC+HP system, the 
condensing temperature of the heat pump increased, and the heating capacity of the heat pump decreased, so the increase rate was lower than that of the SC//HP system.

The input power of the HST+SC and SC+HP systems rose from $2673 \mathrm{~W}$ and $2611 \mathrm{~W}$ to $3128 \mathrm{~W}$ and $2757 \mathrm{~W}$, while the SC/ / HP system kept unchanged at $2655 \mathrm{~W}$. When solar radiation rose by $100 \mathrm{~W} / \mathrm{m}^{2}$, the input power of the HST $+\mathrm{SC}, \mathrm{SC}+\mathrm{HP}$ and $\mathrm{SC} / / \mathrm{HP}$ systems increased by $55 \mathrm{~W}, 16 \mathrm{~W}$, and $0 \mathrm{~W}$, respectively. The increase rate of the HST+SC system was the biggest because as the solar radiation increased, the heat pump evaporation temperature, the evaporation pressure, the refrigerant specific volume, the refrigerant mass flow, the compressor power consumption, and the system input power all increased. As the solar radiation increased, the condensing temperature, condensing pressure and compression ratio of the heat pump in the $\mathrm{SC}+\mathrm{HP}$ system were increased, and the compression ratio is proportional to the compressor power, thus the compressor power consumption and system input power increased. In the SC/ / HP system, the solar radiation intensity had no impact on the heat pump, and its input power remained unchanged.

The COP of the HST+SC system, SC+HP system and SC//HP rose from 2.03, 1.07 and 1.04 to $2.68,4.05$ and 4.11 , respectively. When $\mathrm{I}<400 \mathrm{~W} / \mathrm{m}^{2}$, the COP of the HST+SC system was the largest. When I $>586 \mathrm{~W} / \mathrm{m}^{2}$, the COP of the $\mathrm{SC} / / \mathrm{HP}$ system was the largest. When radiation intensity was $400 \mathrm{~W} / \mathrm{m}^{2}-585 \mathrm{~W} / \mathrm{m}^{2}$, the $\mathrm{SC}+\mathrm{HP}$ system had the best performance.

\subsection{The Effect of Outdoor Air Temperature}

Setting the solar radiation intensity as $500 \mathrm{~W} / \mathrm{m}^{2}$ and when the outdoor air temperature range was $-5^{\circ} \mathrm{C}-20^{\circ} \mathrm{C}$, the variations in the circulating fluid's temperature at the evaporator's inlet and the heat transfer of the heat-source tower in each system with outdoor air temperature are presented in Figure 8. The changes in system heating capacity, input power and COP with outdoor temperature are presented in Figure 9.

Figure 8 shows that as the outdoor temperature rose, the inlet temperature of the circulating fluid and the heat exchange of the heat-source tower both increased. When $\mathrm{I}=500 \mathrm{~W} / \mathrm{m}^{2}$ and $\mathrm{T}_{\mathrm{a}}$ rose from $-5^{\circ} \mathrm{C}$ to $20^{\circ} \mathrm{C}$, the temperature of circulating fluid at the heat pump evaporator's inlet in the HST+SC system rose from $-0.6^{\circ} \mathrm{C}$ to $20.1{ }^{\circ} \mathrm{C}$. The reason is that in the HST+SC system, the circulating fluid flowed through the heat-source tower and solar collectors in turn after flowing out of the heat pump evaporator. When ambient temperature rose, the heat absorbed by the circulating fluid in the heat-source tower increased continuously, thus the outlet temperature of the circulating fluid rose. Then, the circulating fluid flowed out of the heat-source tower and entered the solar collectors. The temperature of circulating fluid at the solar collector's inlet increased, yet the rate of increase was less than that of the ambient temperature. The heat dissipated by the solar collector to the surrounding environment decreased, and the heat transferred to the circulating fluid increased, thus the temperature of circulating fluid at the solar collector's outlet increased. After flowing out of solar collectors, the circulating fluid entered the heat pump evaporator, thereby the temperature of circulating fluid in the heat pump's inlet evaporator increased. The temperature of circulating fluid at the heat pump evaporator's inlet in the $\mathrm{SC}+\mathrm{HP}$ system increased from $-8.0^{\circ} \mathrm{C}$ to $12.3^{\circ} \mathrm{C}$. This is because when the ambient air temperature rose, the heat transfer temperature difference between the circulating fluid and the air in the heat-source tower increased, and the heat absorbed by the circulating fluid increased. It made the temperature of circulating fluid at the heat-source tower's outlet increase, that is, the temperature of circulating fluid at the heat pump evaporator's inlet increased. The temperature of circulating fluid at the heat pump evaporator's inlet in the SC//HP system increased from $-8.0^{\circ} \mathrm{C}$ to $12.2^{\circ} \mathrm{C}$, which was mainly due to the temperature difference between the circulating fluid and the air in the heat-source tower increasing as the ambient temperature rose, thus the heat transfer and the temperature of circulating fluid at the heat-source tower's outlet increased, which means the temperature of circulating fluid at the heat pump evaporator's inlet increased. 


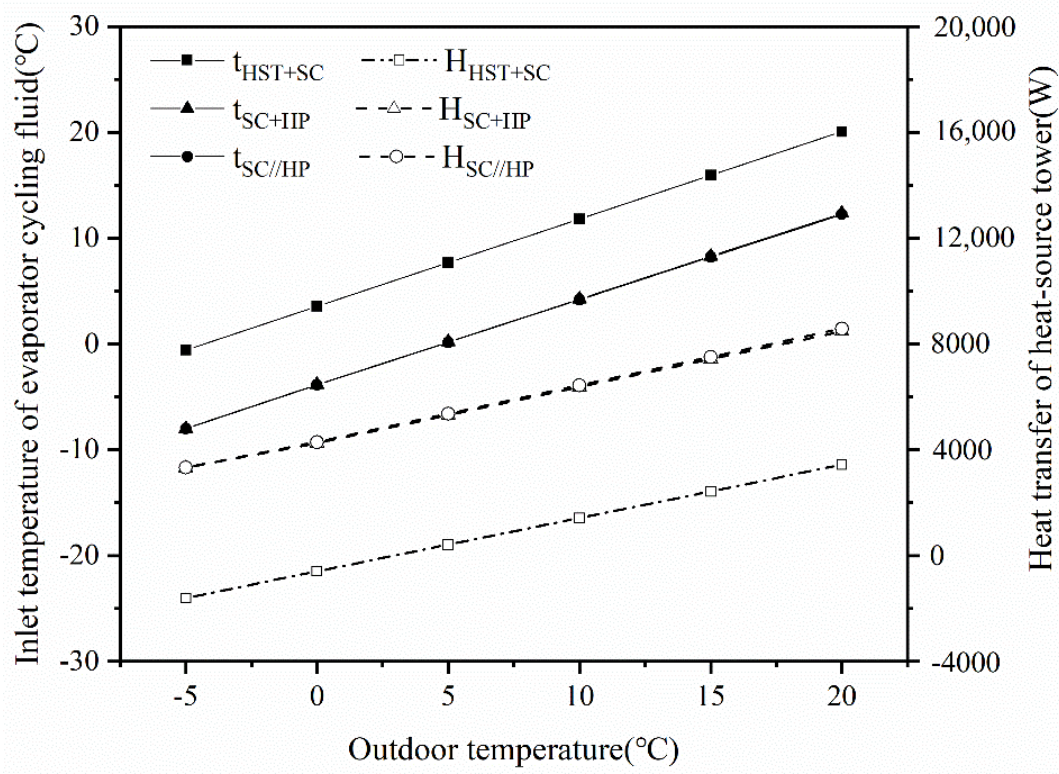

Figure 8. The change in the circulating fluid's temperature of heat pump's inlet and the heat transfer of heat-source tower with the outdoor temperature $\left(I=500 \mathrm{~W} / \mathrm{m}^{2}\right)$.
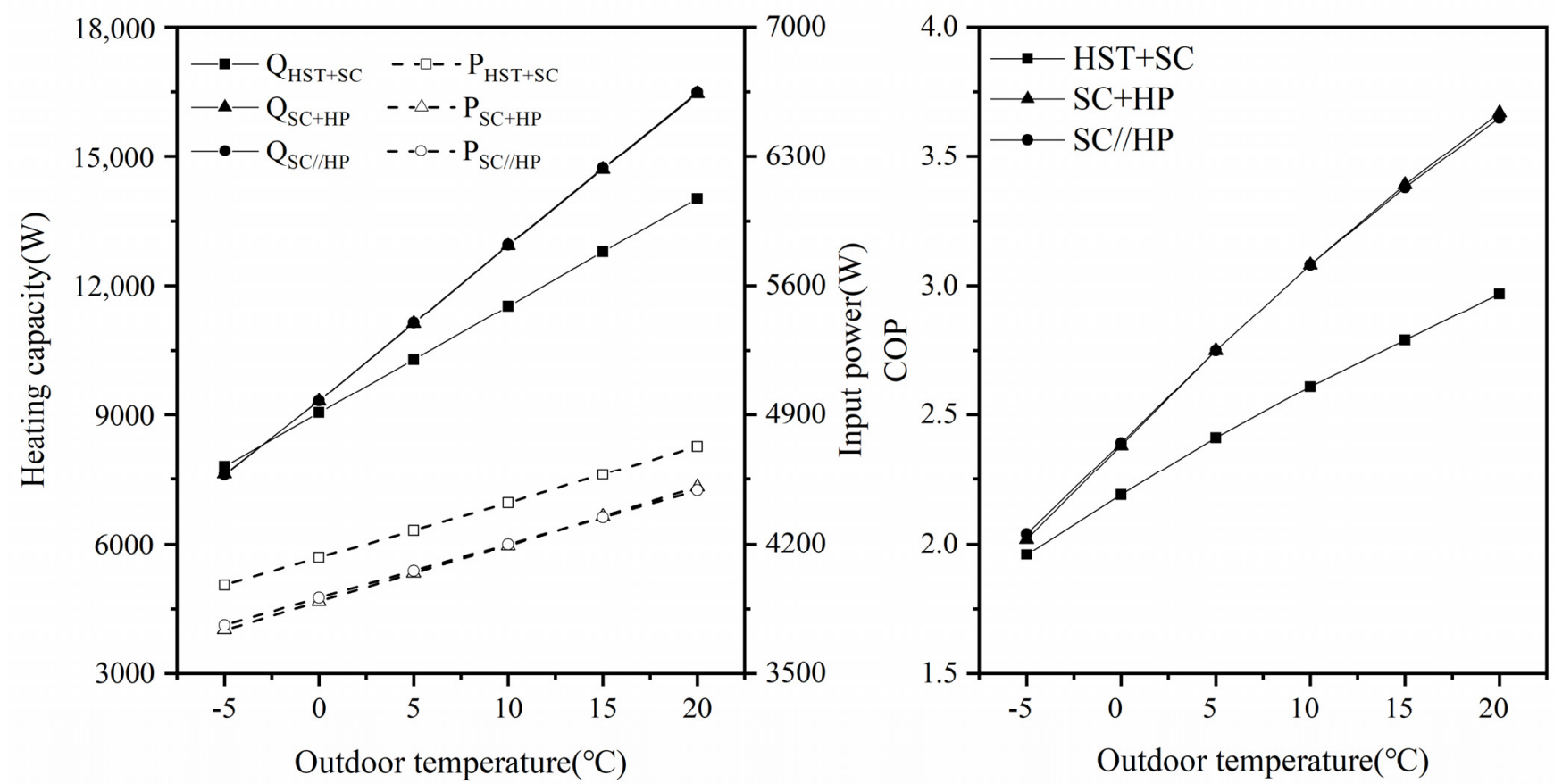

Figure 9. The change in system heating capacity, input power and COP with the outdoor temperature $\left(I=500 \mathrm{~W} / \mathrm{m}^{2}\right)$.

With the rise in outdoor temperature from $-5{ }^{\circ} \mathrm{C}$ to $20^{\circ} \mathrm{C}$, the heat transfer capacity of the heat-source tower in the HST+SC system, SC+HP system and SC/ / HP system increased from $-1602 \mathrm{~W}, 3319 \mathrm{~W}$ and $3326 \mathrm{~W}$ to $3434 \mathrm{~W}, 8472 \mathrm{~W}$ and $8577 \mathrm{~W}$, respectively. The foregoing analysis shows that both the circulating fluid's temperature at the heat pump evaporator's inlet in each system and the heat transfer of the heat-source tower increased with the rise in ambient temperature. In the SC+HP system and the SC/ / HP system, the heat transfer of the heat-source tower was equal to the heat released by the circulating fluid to the refrigerant in the heat pump evaporator. The higher the heat pump evaporator's inlet temperature, the higher the heat pump evaporating temperature, which increased the heat pump heating capacity and the heat released by the circulating fluid to the refrigerant. Hence, the heat transfer of the heat-source tower in the SC+HP system 
and SC / / HP system increased. In the HST+SC system, the circulating fluid's temperature at the heat pump evaporator's inlet rose from $-0.6^{\circ} \mathrm{C}$ to $20.1^{\circ} \mathrm{C}$, and the temperature increase rate of the circulating fluid's temperature at the inlet was less than the increase rate of ambient temperature. Meanwhile, the higher the heat pump evaporator's inlet temperature, the greater the heat released by circulating fluid in the evaporator to the refrigerant. Therefore, the temperature increase rate of the circulating fluid's temperature at the heat pump evaporator's outlet was less than the air temperature increase rate, that is, the increase rate of the circulating fluid's temperature at the heat-source tower's inlet was less than the air temperature increase rate, and the heat exchange temperature difference between circulating fluid and air in the heat-source tower increased, thus the heat transfer of the heat-source tower of the HST+SC system increased.

Figure 9 shows that when $\mathrm{I}=200 \mathrm{~W} / \mathrm{m}^{2}$ and $\mathrm{T}_{\mathrm{a}}$ rose from $-5^{\circ} \mathrm{C}$ to $20^{\circ} \mathrm{C}$, the heating capacity of the HST+SC system, SC+HP system and SC//HP system increased from $7797 \mathrm{~W}, 7614 \mathrm{~W}$ and $7600 \mathrm{~W}$ to $14,022 \mathrm{~W}, 16,456 \mathrm{~W}$ and $16,492 \mathrm{~W}$, respectively. When the solar radiation rose by $100 \mathrm{~W} / \mathrm{m}^{2}$, the heating capacity of the HST+SC, SC+HP and SC/ / HP systems increased by $692 \mathrm{~W}, 982 \mathrm{~W}$ and $988 \mathrm{~W}$, respectively. The heating capacity increase rate of each combined heating system was different. As the increase in outdoor temperature would only increase the heating capacity of WSHP in the HST+SC system, while the SC/ / HP and SC $+\mathrm{HP}$ systems also increased the heating capacity of WSHP and solar collectors, thus the HST+SC system was the least capable of heating among the three. Compared with the SC/ / HP system, the SC+HP system had a smaller increase rate in heating capacity due to the fact that it increased the heat pump condensing temperature and reduced a part of the heat pump's heating capacity.

With the rise of $\mathrm{T}_{\mathrm{a}}$ from $-5^{\circ} \mathrm{C}$ to $20^{\circ} \mathrm{C}$, the input power of the HST+SC system, $\mathrm{SC}+\mathrm{HP}$ system and SC/HP system increased from $3979 \mathrm{~W}, 3734 \mathrm{~W}$ and $3763 \mathrm{~W}$ to $4727 \mathrm{~W}, 4508 \mathrm{~W}$ and $4488 \mathrm{~W}$, respectively. The SC+HP system had the largest increase rate among the three because, due to the ambient temperature rise, the evaporation temperature and condensing temperature in the heat pump of the SC+HP system increased, and the heat pump power increased by a large amount. The power increase rate of the HST+SC system was larger than that of the $\mathrm{SC} /$ /HP system because the heat collected by the heat-source tower, the heat transferred by solar collectors and the evaporation temperature of the HST+SC system all increased, while only the heat transfer of the heat-source tower increased in the SC/ / HP system.

The COP of the three systems all increased with the increase in ambient temperature. When $\mathrm{T}_{\mathrm{a}}$ rose from $-5^{\circ} \mathrm{C}$ to $20^{\circ} \mathrm{C}$, the COP of the HST+SC system, SC+HP system and $\mathrm{SC} /$ / HP system increased from 1.96, 2.04 and 2.02 to 2.97, 3.65 and 3.67, respectively. The $\mathrm{HST}+\mathrm{SC}$ system obtained the smallest COP among them. When $\mathrm{T}_{\mathrm{a}}<10^{\circ} \mathrm{C}$, the COP of the $\mathrm{SC}+\mathrm{HP}$ system was greater than that of the other two systems, and when $\mathrm{T}_{\mathrm{a}}>10{ }^{\circ} \mathrm{C}$, the performance of the SC/ / HP system was best.

Figure 10 shows that when $\mathrm{I}=200 \mathrm{~W} / \mathrm{m}^{2}$ and $\mathrm{T}_{\mathrm{a}}$ rose from $-5{ }^{\circ} \mathrm{C}$ to $20{ }^{\circ} \mathrm{C}$, the $\mathrm{COP}$ of the HST+SC system, SC+HP system, and SC//HP system increased from 1.71, 0.93 and 0.92 to $2.79,2.78$ and 2.75, respectively. Among them, the COP of the HST+SC system was the maximal, and the SC//HP system was the worst because the heating capacity of the SC+HP and SC/ / HP systems was equal to the sum of the heat generated by the heat pump and the heat transferred from solar collectors to hot water. Under low solar radiation, the inlet water temperature of the solar collectors of three systems was high, thus the heat transferred to water by the solar collectors was small or even less than 0, while the HST+SC system took full advantage of solar energy and improved the heat pump's evaporation temperature at low solar radiation. Therefore, the $\mathrm{HST}+\mathrm{SC}$ had the maximum COP. When $\mathrm{I}=900 \mathrm{~W} / \mathrm{m}^{2}$ and $\mathrm{T}_{\mathrm{a}}$ was between $-5^{\circ} \mathrm{C}$ and $20^{\circ} \mathrm{C}$, the COP of the HST+SC system, SC+HP system and SC / / HP system increased from 2.27, 3.48 and 3.49 to 3.12, 4.78 and 4.90, respectively. Among the three systems, the COP of the SC/ / HP system was the maximal, and the HST+SC system was the worst. This is because when the solar radiation was high, the hot water obtained more heat, while for the HST+SC system, its heat pump evaporation temperature increased yet the system performance improvement 
was small. Therefore, the HST+SC system obtained the smallest COP. Meanwhile, the heat pump condensing temperature of the SC+HP system was relatively high under high solar radiation intensity, so its performance was worse than that of the SC/ / HP system.
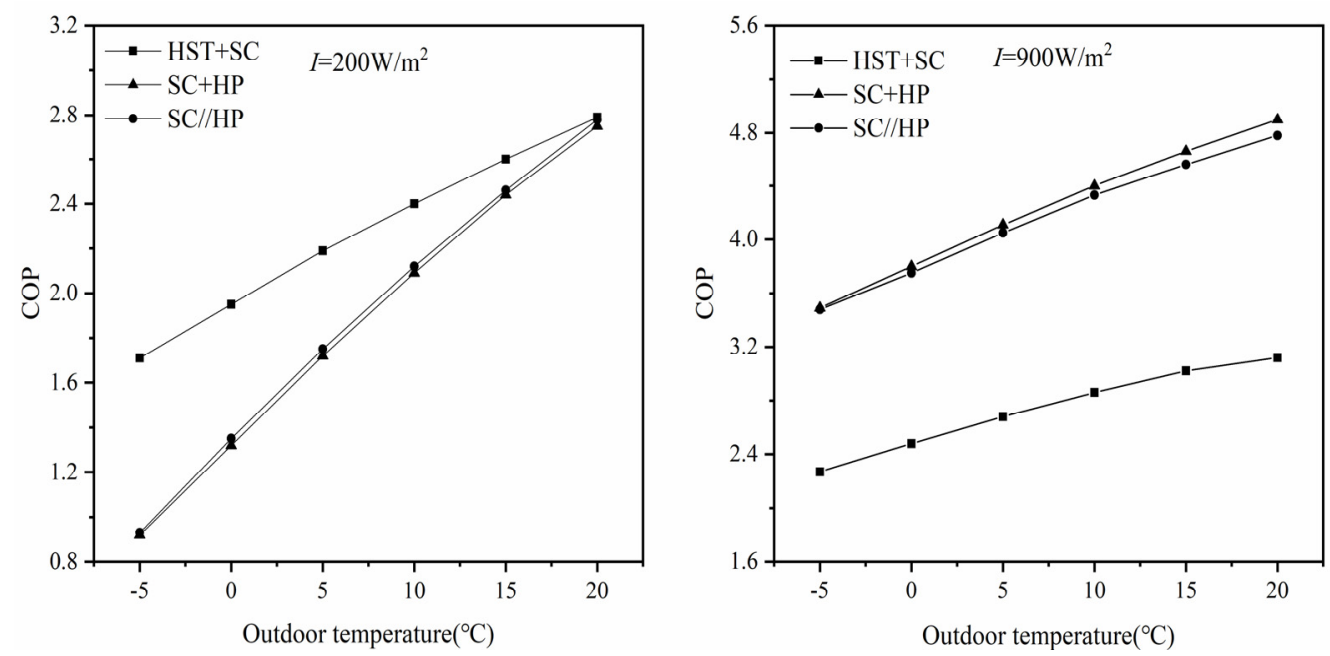

Figure 10. The COP change of three systems with outdoor temperature under different solar radiation intensities.

\subsection{The Optimal Energy Efficiency Range}

From the above analysis, it can be seen that the SC+HP, SC / / HP and HST+SC systems had their own environmental ranges with the largest COP, which was defined as the optimal operating condition range in this paper. The optimal operating condition range of the three systems could be presented in the $I-T$ graph composed of solar radiation intensity $\left(0 \mathrm{~W} / \mathrm{m}^{2}-900 \mathrm{~W} / \mathrm{m}^{2}\right)$ and ambient temperature $\left(-5{ }^{\circ} \mathrm{C}-20^{\circ} \mathrm{C}\right)$. Comparing the COPs of the three systems, the optimum operating condition of the three systems is presented in Figure 11.

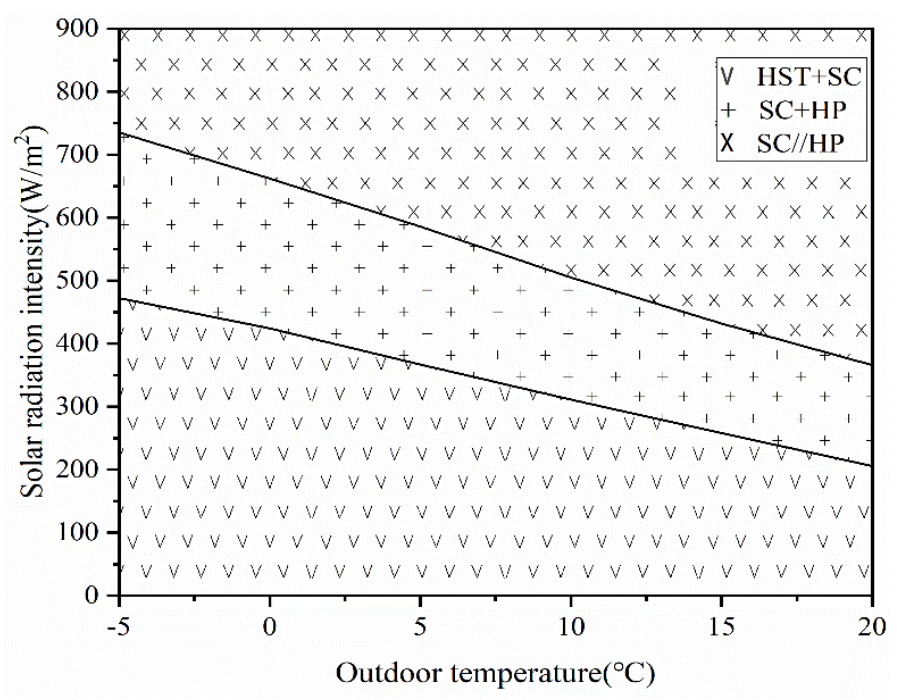

Figure 11. The optimal operating range of the three systems.

Figure 11 shows that the optimal operating condition range of the HST+SC system is mainly located under the condition of lower solar radiation intensity, and at low outdoor air temperature, the solar radiation area of its optimal operating condition is larger. The SC/ / HP system's optimal operating conditions range is mainly in the case of high solar radiation, and when the outdoor air temperature is higher, the greater the range of solar radiation intensity in its best operating conditions. The optimal operating condition range 
of the SC+HP system is relatively small, between the HST+SC and SC//HP system. In summary, under the conditions of low solar radiation and low outdoor air temperature, the heating performance of the HST+SC system is better than the other two systems, and the HST+SC system should be used for heating. However, when the solar radiation intensity and ambient temperature are high, the heating performance of the $\mathrm{SC} / / \mathrm{HP}$ system is the best, and the SC//HP system should be used for heating. When the solar radiation intensity and outdoor air temperature are between the previous two working conditions, the $\mathrm{SC}+\mathrm{HP}$ system has the best heating performance, and the $\mathrm{SC}+\mathrm{HP}$ system should be used for heating.

\section{Conclusions}

In this work, the combined heating technology of a heat-source tower heat pump and solar collectors was studied, and three combined heating systems were established: (i) the HST+SC system with solar collectors connected in series with a heat-source tower, (ii) the $\mathrm{SC}+\mathrm{HP}$ system with solar collectors connected in series with a heat pump condenser, and (iii) the SC/ / HP system with solar collectors connected in parallel with a heat pump condenser. In the cold season, the performance of the three systems was compared and evaluated by TRNSYS software, and the following conclusions are drawn.

(1) The maximum relative error between the experimental value and the simulated value of the outlet temperature of the circulating fluid of the heat-source tower and the amount of heat exchange is $7.32 \%$ and $9.94 \%$, respectively, showing that the TRNSYS calculation module of the heat-source tower built in this work had good accuracy and could be used for the simulation and calculation of three combined heating systems with collectors and a heat-source tower heat pump.

(2) In the HST+SC system, when solar radiation intensity increased, the heat exchange amount of the heat-source tower decreased with the increase in solar radiation intensity, which indicated that the solar collectors suppressed the heat transfer efficiency of the heat-source tower.

(3) According to the best operating condition interval diagrams of the three systems, the $\mathrm{HST}+\mathrm{SC}$ system has the best heating performance under the conditions of low solar radiation intensity and ambient temperature, while the best operating condition range of the SC//HP system is mainly under conditions of high solar radiation intensity and high ambient temperature. The optimal operating conditions range of the $\mathrm{SC}+\mathrm{HP}$ system is between the HST+SC and SC//HP systems.

Author Contributions: Conceptualization, X.S.; methodology, X.S.; software, X.S. and Y.A.; validation, X.S. and N.L.; writing: original draft preparation, X.S. and N.L.; writing: review and editing, N.L. and Y.A.; supervision, N.L. All authors have read and agreed to the published version of the manuscript.

Funding: This study received no funding.

Data Availability Statement: No new data were created or analyzed in this study. Data sharing is not applicable to this article.

Conflicts of Interest: The authors declare no conflict of interest.

\section{Nomenclature}

$A_{\mathrm{L}}$

$A_{\mathrm{O}}$

$A_{\mathrm{S}}$

$C_{\mathrm{pa}}$

$C_{\mathrm{pw}}$

$C_{\mathrm{d}}$

$\mathrm{C}_{\mathrm{W}}$
The total area inside the heat-source tower heat exchanger, $\mathrm{m}^{2}$ The total area outside the heat-source tower heat exchanger, $\mathrm{m}^{2}$ Solar collector, $\mathrm{m}^{2}$ Constant pressure specific heat capacity of humid air, J/( $\mathrm{kg} \cdot \mathrm{K})$ Constant pressure specific heat capacity of heat carrier fluid, $\mathrm{J} /(\mathrm{kg} \cdot \mathrm{K})$ Heat capacity ratio of cold and hot fluid in heat-source tower heat exchanger under dry conditions Heat capacity ratio of cold and hot fluid in heat-source tower heat exchanger under wet conditions 


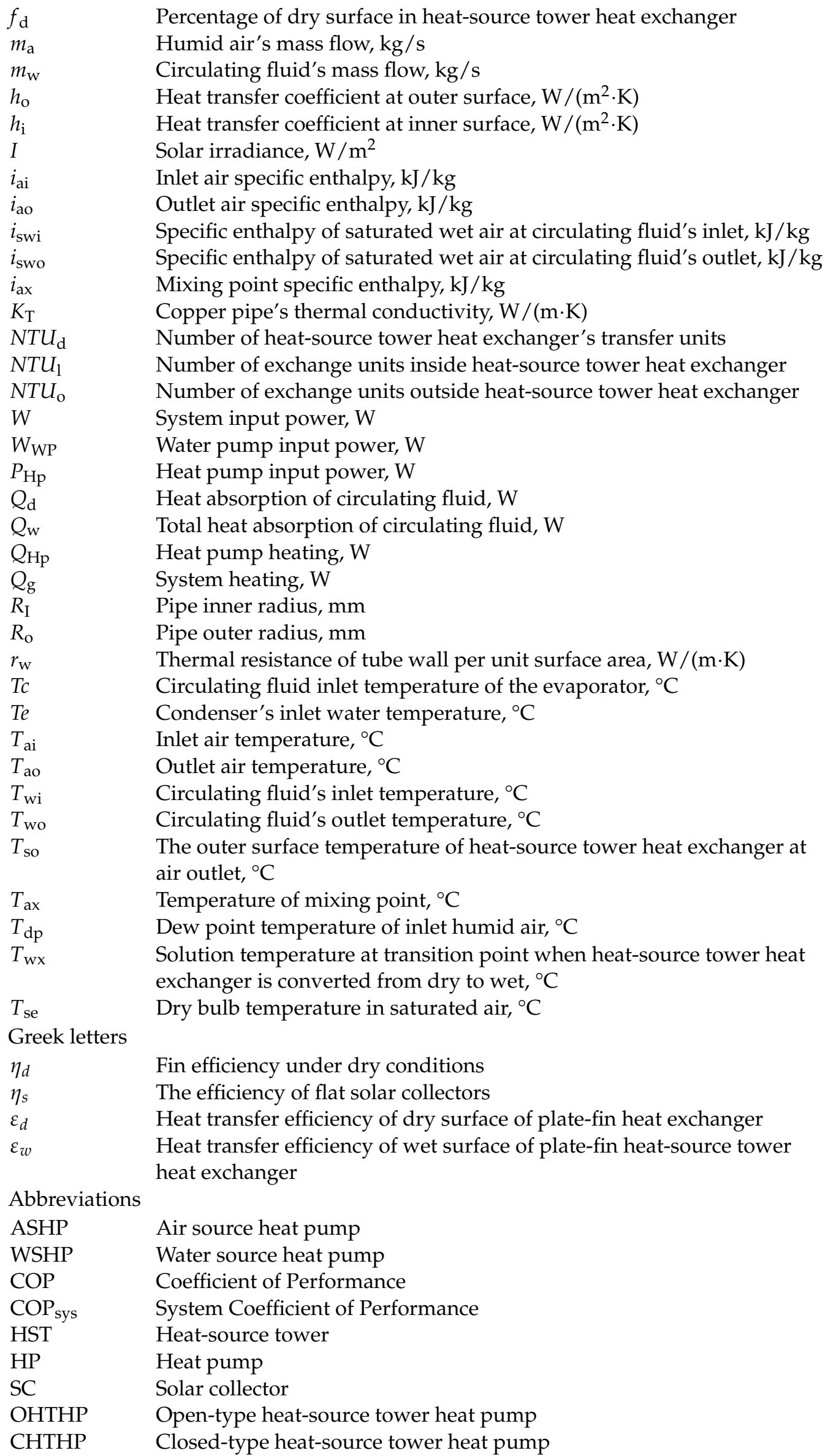




\section{References}

1. Bellos, E.; Tzivanidis, C.; Moschos, K.; Antonopoulos, K. Energetic and Financial Evaluation of Solar Assisted Heat Pump Space Heating Systems. Energy Convers. Manag. 2016, 120, 306-319. [CrossRef]

2. Raimonds, B.; Borodinecs, A.; Zajacs, A.; Steinerte, A. Review of Heat Pumps Application Potential in Cold Climate. In Energy Management of Municipal Transportation Facilities \& Transport; Springer: Cham, Germany, 2017.

3. Zajacs, A.; Lalovs, A.; Borodinecs, A.; Bogdanovics, R. Small Ammonia Heat Pumps for Space and Hot Tap Water Heating. Energy Procedia 2017, 122, 74-79. [CrossRef]

4. Jonas, D.; Frey, G.; Theis, D. Simulation and Performance Analysis of Combined Parallel Solar Thermal and Ground or Air Source Heat Pump Systems. Sol. Energy 2017, 150, 500-511. [CrossRef]

5. Long, J.; Lu, J.; Jiang, M.; Du, A.; Zhang, R.; A, Y. Study on Solar Energy Utilization Characteristics of a Solar Building Integrated Wall. Appl. Therm. Eng. 2020, 175, 115289. [CrossRef]

6. Zajacs, A.; Borodiecs, A.; Neviero, I. Optimal Use of Solar Collectors in Small-Scale Districts. In Proceedings of the IOP Conference Series Materials Science and Engineering, Hanoi, Vietnam, 23-26 September 2020; Volume 869, p. 42039.

7. Qiu, G.; Wei, X.; Xu, Z.; Cai, W. A Novel Integrated Heating System of Solar Energy and Air Source Heat Pumps and its Optimal Working Condition Range in Cold Regions. Energy Convers. Manag. 2018, 174, 922-931. [CrossRef]

8. Huang, S.; Zuo, W.; Lu, H.; Liang, C.; Zhang, X. Performance Comparison of a Heating Tower Heat Pump and an Air-Source Heat Pump: A Comprehensive Modeling and Simulation Study. Energy Convers. Manag. 2019, 180, 1039-1054. [CrossRef]

9. Song, Y.; Ma, H.; Long, W. Application and Analysis of Energy Tower Heat Pump Technology in Air Conditioning Engineering. Heat. Vent. Air Cond. 2011, 41, 20-23.

10. Liu, Q.; Wang, W. The Application of Heat-Source-Tower in South of China. Archit. Sci. 2008, 19, 94-95.

11. Li, N.; Zhang, W.; Wang, L.; Liu, Q.; Hu, J. Experimental Study on Energy Efficiency of Heat-Source Tower Heat Pump Units in Winter Condition. Int. Conf. Meas. Technol. Mechatron. Autom 2011, 2, 135-138.

12. Liang, C.; Wen, X.; Zhang, X. Construction and Experiment Research Heat Pump System Based on Heat-Source Tower. Ciesc J. 2010, 61, 142-146.

13. Lu, J.; Li, W.; Li, Y.; Yang, L.; Xie, L.; Li, Q.; Wang, M. Numerical Study on Heat and Mass Transfer Characteristics of the Counter-Flow Heat-Source Tower (CFHST). Energy Build. 2017, 145, 318-330. [CrossRef]

14. Fujita, T.; Kametani, S. Thermal Characteristics of Heating Towers. Trans. Jpn. Soc. Refrig. Air. Cond. Eng. 2012, 6, $265-274$.

15. Huang, S.; Lv, Z.; Zhang, X.; Liang, C. Experimental Investigation on Heat and Mass Transfer in Heating Tower Solution Regeneration Using Packing Tower. Energy Build. 2018, 164, 77-86. [CrossRef]

16. Huang, S.; Lu, X.; Zuo, W.; Zhang, X.; Liang, C. Model-Based Optimal Operation of Heating Tower Heat Pump Systems. Build. Environ. 2019, 160, 106199. [CrossRef]

17. Wen, X.; Liang, C.; Zhang, X. Experimental Study on Heat Transfer Coefficient Between Air and Liquid in the Cross-Flow Heat-Source Tower. Build. Environ. 2012, 57, 205-213. [CrossRef]

18. Liang, C.; Wen, X.; Liu, C.; Zhang, X. Performance Analysis and Experimental Study of Heat-Source Tower Solution Regeneration. Energy Convers. Manag. 2014, 85, 596-602. [CrossRef]

19. Zhang, C.; Yang, H.; Liu, Q.; Wu, J. Analysis of Closed-Type Heat-Source Tower Used in Air Conditioning System. Build Energy Environ. 2009, 28, 71-73.

20. Cheng, J.; Li, N.; Wang, K. Study of Heat-Source-Tower Heat Pump System Efficiency. Procedia Eng. 2015, 121, 915-921. [CrossRef]

21. Chen, Q.; Li, N.; Cheng, J.; He, Z. Experimental Research on Heat Exchange Performance of Closed Heat-Source Tower. Heat Vent. Air Cond. 2015, 45, 68-71.

22. Jia, J.; Li, N.; Peng, J.; Zhang, N.; Cheng, J.; Cui, H. Heat and Mass Exchange Model of Cross-Flow Heat-Source Tower Based on $\varepsilon$-NTU Method. J. Refrig. 2019, 40, 66-73.

23. Li, N.; Zhang, D.; Cheng, J.; He, Z.; Chen, Q. Economic Analysis of Heat-Source Tower Heat Pump Air Conditioning System. J. Shenzhen Univ. 2015, 32, 404-410. [CrossRef]

24. Song, P.; Wang, B.; Li, X.; Shi, W. Experimental Research on Heat and Mass Transfer Characteristics of Cross-Flow Closed-Type Heat-Source Tower. Appl. Therm. Eng. 2018, 135, 289-303. [CrossRef]

25. Song, P.; Li, X.; Wang, B.; Shi, W. Experimental Study on Solution Regeneration Performance of Closed-type Heat-source Tower. Procedia Eng. 2017, 205, 446-452. [CrossRef]

26. Long, J.; Zhang, R.; Lu, J.; Xu, F. Heat Transfer Performance of an Integrated Solar-Air Source Heat Pump Evaporator. Energy Convers. Manag 2019, 184, 626-635. [CrossRef]

27. Long, J.; Xia, K.; Zhong, H.; Lu, H. Study on Energy-Saving Operation of a Combined Heating System of Solar Hot Water and Air Source Heat Pump. Energy Convers. Manag. 2021, 229, 113624. [CrossRef]

28. Kim, T.; Choi, B.; Han, Y.; Do, K. A Comparative Investigation of Solar-Assisted Heat Pumps with Solar Thermal Collectors for a Hot Water Supply System. Energy Convers. Manag. 2018, 172, 472-484. [CrossRef]

29. Cheng, J.; Zou, S.; Chen, S. Application Research on the Closed-loop Heat-Source-Tower Heat Pump Air Conditioning System in Hot-Summer and Cold-Winter Zone. Procedia Eng. 2015, 121, 922-929. [CrossRef]

30. Feng, R.; Liu, Y.; Fang, J.; Meng, X. Heating Performance of Solar Assisted Closed-Type Heating Tower Heat Pump System in Winter. Proc. Trans. Chin. Soc. Agric. Eng. 2020, 36, 210-217. 
31. Zhang, W. The Basic Investigation on Application of Solar Thermal Heat-Source Tower Heat Pump (STHSTHP) System; Tianjin University: Tianjin, China, 2010.

32. Xia, Y.; Li, H.; Zhang, Z.; Wen, Y.; Guo, Q.; Xu, Q. Study on Composite Air Conditioning System of Solar-Heat Source Tower Heat Pump in Wuhan Area. Refrig. Air-Cond. 2019, 19, 62-68.

33. Shi, S.; Li, N.; Luo, P.; Li, S. Performance Analysis of Solar Hot Water System Assisted by Heat-Source Tower Heat Pump in Changsha. Sci. Technol. Eng. 2016, 16, 204-209.

34. Braun, J.E.; Klein, S.A.; Mitchell, J.W. Applications of Optimal Control to Chilled Water Systems Without Storage. ASHRAE Trans. 1989, 95, 663-675.

35. Zhang, Y.; Long, E.; Zhao, X.; Jin, Z.; Liu, Q.; Liang, F.; Ming, Y. Combined Solar Heating and air-Source Heat Pump System with Energy Storage Thermal Performance Analysis and Optimization. Procedia Eng. 2017, 205, 4090-4097.

36. Jung, Y.; Kim, J.; Kim, H.; Yun, R.; Park, C.; Nam, Y.; Cho, H.; Hoseong, L.A. Comprehensive Feasibility Investigation of River Source Heat Pump Systems in Terms of Life Cycle. Appl. Therm. Eng. 2021, 188, 116655. [CrossRef] 